УДК 378.147091.33-027.22:7

DOI:

Олена Семенова, кандидат педагогічних наук, доцент кафедри образотворчого мистецтвва Уманського державного педагогічного університету імені Павла Тичини Ольга Бикова, кандидат педагогічних наук, доцент кафедри хореографії та художньої культури Уманського державного педагогічного університету імені Павла Тичини

\title{
ПРАКТИЧНА ПІДГОТОВКА СТУДЕНТІВ МИСТЕЦЬКИХ СПЕЦАЛЬНОСТЕЙ: ПЕДАГОГІЧНА ТА ТВОРЧА СКЛАДОВІ
}

Педагогічна практика - важливий етап у підготовиі майбутніх вчителів мистецьких дисциплін, позаяк сформовані професійні компетентності допоможуть здобувачам розкрити свій творчий потенціал у подальшій професійній діяльності. У статті розглядається досвід організації педагогічної практики студентів спеціальності “024 Хореографія" та “014 Середня освіта. Образотворче мистеитво” в УДПУ імені Павла Тичини. Розкривається специффіка проведення та види навчальної практики: навчально-творча (пленер), навчально-фольклорна, практика керівника хореографічного колективу, як обов 'язкового компонента освітнього процесу. Висвітлюється мета та завдання кожного виду практики. Авторами статті робиться висновок про педагогічну практику як ключову ланку підготовки кваліфікованих фахівців мистецьких спеціальностей.

Ключові слова: педагогічна практика; навчальна практика; творча практика; студенти мистеиьких спеціальностей.

תim. 6.

Elena Semenova, Ph.D.(Pedagogy), Associate Professor of the Fine Arts Department, Uman Pavlo Tychyna State Pedagogical University

Olha Bykova, Ph.D.(Pedagogy), Associate Professor of the Choreography and Art Culture Department, Uman Pavlo Tychyna d State Pedagogical University

\section{PRACTICALTRAINING OF STUDENTS OF ART SPECIALTIES: PEDAGOGICALAND CREATIVE COMPONENTS}

The article is devoted to one of the urgent problems of future teachers of art specialties training - passing pedagogical practice in higher education institutions.

In particular, the concept of "teaching practice" is analyzed. The types of teaching practice that students of art specialties go through are considered. It was found out that students of higher education of the Faculty of Arts at Uman Pavlo Tychyna State Pedagogical University during their studies have several types of teaching practice: folklore practice; training practice of the leader of the choreographic team; educational and creative practice (plein air); teaching practice.

The characteristics of each of the listed types of practice are presented. For example, folklore practice contributes to the holistic training of future teachers of choreography, develops skills for independent creative pedagogical activity, and expands the national and cultural worldview of students who master the methods of search and collection activities.

The training practice of the leader of the choreographic team is designed to give the trainee the opportunity to study the activities of the leader of the choreographic team, during which the graduate must demonstrate their knowledge of professional methods, develop skills and skills to work with choreographic team.

It was found that during the teaching practice students are involved in pedagogical activities and educational work: they observe the educational process, conduct lessons, etc.

The article presents the tasks performed by students of art specialties 024 Choreography and 014 Secondary Education (Fine Arts) during teaching practice.

The authors of the article demonstrate the importance of educational and creative projects, which are an important component of a set of creative tasks. The purpose of educational and creative projects is clarified - the organization of education, in which students acquire knowledge in the process of planning and performing practical tasks.

The article analyzes the structural elements of practical training, which include the following stages: organizational and informational stage, the main content stage, the final stage.

The role of the leader of practice supervisor is considered and his responsibilities are presented.

It is also noted that during the teaching practice students must show both methodological knowledge and their didactic and creative abilities.

Keywords: pedagogical practice; educational practice; creative practice; students of art specialties.

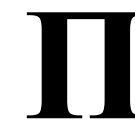

остановка проблеми у загальному вигляді та її зв'язок із важливими науковими чи практичними завданнями. Ступенева система сучасної вищої освіти надає значущої ролі педагогічній практиці в процесі становлення професійних якостей майбутніх педагогів.

Теоретичні знання, які отримує людина, стають 


\section{ПРАКТИЧНА ПІДГОТОВКА СТУДЕНТІВ МИСТЕЦЬКИХСПЕЦАЛЬНОСТЕЙ: ПЕДАГОГІЧНА ТА ТВОРЧАСКЛАДОВІ}

iï переконаннями лише тоді, коли вона навчиться застосовувати їх на практиці [1, 49]. Саме тому, педагогічна практика $є$ видом навчальної діяльності студента та обов'язковим компонентом професійної підготовки майбутнього вчителя, завдяки якому здобувач вищої освіти стає суб'єктом навчання і має можливість застосувати отримані ним знання на аудиторних заняттях із теорії і практики, а також використовувати набуті уміння й навички. Здобувачі вищої освіти за час проходження практики розв'язують чимало завдань, які в подальшій професійній діяльності принесуть свої результати. Одним із головних завдань практики $€$ набуття студентами професійних компенетностей для подальшого становлення їх як професіоналів у педагогічній галузі.

Аналіз останніх досліджень і публікацій. Проблемами професійної підготовки майбутніх вчителів займались такі відомі фахівці: А. Алексюк, О. Абдуліна, Л. Вовк, Н. Дем'яненко, І. Зязюн, Н. Ничкало, В. Сластьонін, А. Бойко, І. Котик, Н. Кузьміна, В. Лозова, Р. Попелюшко, Н. Хміль та інші.

Проблеми практичної підготовки відображено у працях Г. Балла, І. Беха, А. Верхоли, П. Гальперіна, М. Козія та інших.

Формування мети статті. Метою статті $\epsilon$ розкриття специфіки проведення творчопедагогічних практик як обов'язкового компонента освітнього процесу на факультеті мистецтв Уманського державного педагогічного університету імені Павла Тичини за освітніми програмами Хореографія та Середня освіта (Образотворче мистецтво).

Виклад основного матеріалу дослідження. Практична підготовка як органічна складова фахової підготовки студентів здійснюється згідно із Законом України “Про освіту”, “Положенням про проведення практики студентів вищих навчальних закладів України", затвердженим наказом МОН України від 8 квітня 1993 р. № 93”. Педагогічна практика є об'єднувальною ланкою між теоретичною підготовкою й власне професійно-практичною діяльністю. Практика в дидактичній науці, визначається як застосування знань у ході виконання вправ, розв'язування завдань [6, 34].

Практична підготовка на факультеті мистецтв проходить згідно із “Положенням про організацію практик в Уманському державному педагогічному університеті імені Павла Тичини (денної та заочної форми навчання)", затвердженим на засіданні вченої ради від 26 січня 2021 року, протокол № 10 відповідно до навчальних планів, у яких наводиться перелік усіх видів практик, їх форми, тривалість та терміни проведення [5].

Практична підготовка факультету мистецтв має кілька складових: творчу та педагогічну. Згідно з навчальними планами спеціальності 024 Хореографія, 014 Середня освіта. Образотворче мистецтво, підготовки бакалаврів до творчої складової слід віднести такі види навчальної практики, як навчально-творча (пленер), навчально-фольклорна, практика керівника хореографічного колективу. За положенням про практики навчальні види практик відбуваються на першому i другому курсах. Коротко охарактеризуємо специфіку педагогічної практики вищезазначених спеціальностей.

Фольклорно-пошукова практика сприяє цілісній підготовці майбутніх вчителів хореографії, розвиває навички до самостійної творчої педагогічної діяльності, розширює світогляд. Збиральницька діяльність допомагає збереженню, популяризації здобутків народної пам'яті, формуванню духовно розвиненої особистості. Збирання фольклорного матеріалу - ефективний спосіб пізнання життєвого устрою, вивчення історії, побуту, обрядів та звичаїв народу. За період практики студенти факультету мистецтв здійснюють збір, систематизацію й опрацювання творів народної творчості.

Фольклорна пошукова робота є важливим засобом залучення студентів до національної матеріальної і нематеріальної культури народу.

Навчальна практика керівника хореографічного колективу призначена для того, аби надати можливість студентові-практиканту вивчити діяльність керівника хореографічного колективу проаналізувати іï; ознайомитися із документацією хореографічного колективу; навчитися планувати роботу в хореографічному колективі; на практиці освоїти організаційно-репетиційні дії керівника; систематизувати весь вивчений матеріал та відповідно його оформити.

Здобувач вищої освіти повинен продемонструвати свої знання з фахових методик, сформувати уміння та навички роботи 3 хореографічними колективом розвивати здатність до опанування теоретичних і практичних завдань роботи керівника хореографічного колективу та успішно їх розв'язувати.

Навчально-творча практика (пленер) проводиться для студентів спеціальності 014 Середня освіта (Образотворче мистецтво) на початку або ж вкінці навчального року, коли погодні умови дають змогу працювати під відкритим небом. При виконанні завдань практики студенти закріплюють вивчені закономірності 


\section{ПРАКТИЧНА ПІДОТОВКА СТУДЕНТІВ МИСТЕЦЬКИХСПЕЦАЛЬНОСТЕЙ: ПЕДАГОГІЧНА ТА ТВОРЧА СКЛАДОВІ}

природного середовища, їх вплив на сприйняття людиною предметів і об'єктів довколишнього світу, особливості та закономірності зображення предметів, об'єктів і явищ засобами рисунка, живопису, композиції.

Здобувачі вищої освіти протягом практики закріплюють знання, отримані на лабораторнопрактичних заняттях протягом навчального року і набувають практичних навичок з рисунка, живопису, композиції, у зображенні начерків деталей пейзажу й архітектурних об'єктів. При виконанні завдань студенти опановують техніки рисунка і живопису та продовжують знайомитися iз своєрідністю художніх матеріалів, що сприяє формуванню у них художнього смаку і розвиток художніх здібностей, розширення знань засобів художньої виразності, технік. Особливістю пленерної практики є те що вона відбувається у природному середовищі, студент має широкі можливості творчого розвитку й імпровізації. В основі виконання завдань навчальної практики від початку до їі завершення лежать дидактичні принципи від більш простого до більш складного, від загального до часткового.

Навчальна педагогічна практика здобувачів вищої освіти ОС “бакалавр” проходить на третьому курсі. Метою практики є ознайомлення iз системою навчально-виховної, позакласної роботи класного керівника, вчителя-предметника та школи загалом; формування уміння конструювати й організовувати окремі елементи процесу навчання у закладах загальної середньої освіти; вивчення досвіду навчально-виховної, позакласної роботи вчителів-предметників та класних керівників у колективах учнів закріплених класів.

Такий вид практики сприяє поглибленню та закріпленню знань із психолого-педагогічних дисциплін, виробленню уміння їх застосування на практиці. За час практики студенти продовжують опановувати уміння і навички самостійного планування, організації та проведення навчальновиховної і методичної роботи в умовах загальноосвітнього закладу. Вивчення та узагальнення накопиченого в закладах загальної середньої освіти передового педагогічного досвіду навчання і виховання школярів, дають змогу майбутнім митцям-педагогам сформувати свій стиль викладання. Завдання навчальної практики сприяють формуванню у студентапрактиканта критичної самооцінки педагогічної діяльності, творчого аналізу педагогічних ситуацій, прагнення до постійного вдосконалення.

Навчальна (пропедевтична) практика спеціальності 024 Хореографія спрямована на підготовку фахівця у галузі хореографічнопедагогічної освіти, проходить на 3 курсі у VI семестрі на базі закладів загальної середньої освіти та позашкільних закладів культури та мистецтв упродовж 4 тижнів. За своїм змістом ця практика сприяє поглибленому вивченню професійної діяльності вчителя-хореографа на основі засвоєних студентом теоретичних та практичних знань, фахових дисциплін і методик ïх навчання, сформованих знань, умінь і навичок з виховної роботи.

Під час проходження навчальної практики студенти залучаються до педагогічної діяльності та навчально-виховної роботи: спостерігають за освітнім процесом, проводять заняття з хореографії та допомагають у підготовці виховних заходів, працюють над хореографічними постановками для дітей, співпрацюють 3 керівництвом закладу, класними керівниками, вчителями хореографії.

Після закінчення практики проводяться підсумкові заходи з різних її видів, використовуючи, як результат, і хореографічні постановки [3].

Відповідно до положень, зазначених у робочій програмі, під час проходження навчальної практики майбутні учителя хореографії отримують певні завдання:

1. 3 метою кращого закріплення та поглиблення теоретичних знань з хореографічних дисциплін студенти мають розробити:

- авторську програму партерного екзерсису для молодших школярів;

- комплекс вправ для усунення фізичних вад у поставі дитини (молодший шкільний вік);

- авторській тренаж із класичного або народносценічного танцю для учнів початкової школи.

2.3 метою оволодіння професійно-педагогічними уміннями студенти розробляють і проводять заняття 3 будь-якого виду хореографії, використовуючи ігрові методи навчання і творчі завдання для розвитку хореографічних та музично-ритмічних здібностей учнів початкових класів.

Запропоновані творчі завдання оцінюються за такими критеріями: знання особливостей психофізіологічного та творчого розвитку дітей різного віку; уміння використовувати комплекс креативних завдань для розвитку (формування) індивідуальних творчих здібностей дітей; уміння розробляти авторські програми 3 партерної гімнастики та тренажу; уміння планувати роботу на уроках хореографії [4].

Працюючи над розробкою партерної гімнастики або комплексу вправ для усунення фізичних вад чи займаючись розробкою уроку з хореографії, студенти демонструють знання 


\section{ПРАКТИЧНА ПЦДОТОВКА СТУДЕНТІВ МИСТЕЦЬКИХ СПЕЦАЛЬНОСТЕЙ: ПЕДАГОГІЧНА ТА ТВОРЧАСКЛАДОВІ}

особливостей психофізіологічного та творчого розвитку дітей, виявляють грунтовні й міцні знання 3 основ хореографічного мистецтва, уміння використовувати комплекс креативних завдань для розвитку індивідуальних творчих здібностей дітей молодшого шкільного віку.

Під час навчальної практики варто відзначити значимість навчально-творчих проєктів, які $€$ важливою складовою комплексу творчих завдань. Мета навчально-творчих проєктів - організація навчання, за якої студенти здобувають знання у процесі планування і виконання практичних завдань - проєктів. Навчально-творчий проєкт це можливість для майбутніх учителів хореографії навчати навчаючись, набуття нового досвіду, вміння працювати у колективі в атмосфері довіри.

Значення навчально-творчих проєктів у підготовці майбутніх учителів хореографії неможливо переоцінити. 3'ясовано, щ, займаючись різними проєктами, студентихореографи набувають умінь аналізувати свої інтереси і бажання, визначати нові інтереси на основі сформованості та розвитку колишніх; зіставляти свої можливості і інтереси; відстоювати свої інтереси.

Навчальна практика (пропедевтична) спеціальності 014 Середня освіта (Образотворче мистецтво) проходить на 3 курсі у VI семестрі на базі закладів загальної середньої освіти упродовж 2 тижнів.

Під час практики студенти ознайомлюються із системою навчально-виховної, позакласної та позашкільної роботи класного керівника, вчителя образотворчого мистецтва та школи загалом; мають змогу вивчати досвід навчально-виховної, позакласної роботи вчителів-предметників та класних керівників у колективах учнів за закріпленими за ними класами.

Згідно з робочими програмами практики, здобувачі вищої освіти ОС “бакалавр” на передодні практики отримують навчальні завдання: розробити та провести виховну годину; розробити, на основі спостережень відвіданих уроків, кілька планів-конспектів уроків із образотворчого мистецтва; провести дослідження учнівського колективу та на його основі написати психолого-педагогічну характеристику;проаналізувавши всю роботу, яку виконував здобувач вищої освіти, написати індивідуальний звіт та відповідно його оформити; ведення щоденника психологопедагогічних спостережень. Крім навчальних завдань, студенти планують і виховну роботу: відвідують та беруть участь в організації виховних заходів, допомагають у підготовці і проведенні образотворчих, мистецтвознавчих, історико- культурних вікторин, лекцій, тематичних виставок, конкурсів тощо.

У будь-якому із видів практик можна виокремити такі структурні елементи: організаційно-інформаційний етап, основний змістовий етап, підсумковий етап [2].

При складанні індивідуального плану роботи здобувач вищої освіти враховує кожен із зазначених етапів. Так, на адаптаційному етапі відбувається планування: участь в настановній конференції, знайомство із школою, педагогічним колективом, вчителями-предметниками, закріпленим класом і їх класним керівником, знайомство із матеріальною базою, внутрішнім розпорядком школи, документацією.

На етапі ідентифікації (основному) відбувається знайомство 3 календарними та поурочними планами, спостереження уроків вчителів-предметників, складання та проведення пробних уроків, підготовки і проведення виховної години, спостереження за колективом.

Підсумковий етап охоплює такі завдання: написати звіт про проходження педагогічної практики, оформити документацію, взяти участь у підсумковій конференції з педагогічної практики.

Відповідальність за організацію і проведення практичної підготовки студентів покладається безпосередньо на керівників закладів вищої освіти. Навчально-методичне керівництво і виконання програм практики забезпечують відповідні кафедри факультету мистецтв і кафедра педагогіки та освітнього менеджменту. Загальну організацію практики студентів та контроль за іï проведенням здійснюють керівник практик від кафедр і факультету.

До обов'язків групових керівників-методистів входять:

- проведення інструктажу із техніки безпеки та охорони праці студентів;

- забезпечення необхідною документацією методистів, керівників баз практик, студентів;

- допомога студентам при складанні індивідуального плану роботи період практики;

- проведення настановчої та підсумкової конференцій;

- допомога студентам у веденні звітної документації;

- допомога у підготовці залікових уроків, виховних заходів, які будуть проводитися студентом-практикантом, а також відвідування залікових виховних заходів, уроків, аналіз і їх оцінювання.

Під час практики студент повинен показати як знання із предмета, так і свої дидактичні здібності: вміло та в доступній формі пояснювати 


\section{ПРАКТИЧНА ПДГОТОВКА СТУДЕНТІВ МИСТЕЦЬКИХ СПЕЦАЛЬНОСТЕЙ: ПЕДАГОГІЧНА ТА ТВОРЧА СКЛАДОВІ}

навчальний матеріал з урахуванням віку учнів; використовувати різні методи та прийоми навчання; зацікавлювати змістом викладеного матеріалу, володіти прийомами риторики - чітко і красномовно висловлюватись.

Висновки 3 даного дослідження і перспективи подалыших розвідок у даному напрямку. Отже, педагогічна практика $є$ особливою формою організації процесу навчання, завдяки якій оцінюються отриманий досвід і рівень сформованості професійних знань та вмінь. Саме тому добре продумана організація педагогічної практики на всіх рівнях її підготовки та проведення, поступове ускладнення іiі завдань, змісту, пошуки нових форм забезпечать формування професійних компетентностей майбутніх вчителів мистецьких спеціальностей. На нашу думку, педагогічна практика у ЗВО здатна сформувати лише початковий педагогічний досвід, який студентам в подальшому потрібно збагачувати. Перспективами подальшого розроблення заявленої проблеми бачимо розроблення навчально-методичних рекомендацій iз проходження педагогічної практики для студентів факультету мистецтв УДПУ імені Павла Тичини.

\section{ЛІТЕРАТУРА}

1. Абдуллина О. А. Педагогическая практика студентов. Москва, 1989. 175 с.

2. Ворожбіт-Горбатюк В., Мельникова О., Кабанська Г. Науково-педагогічна практика здобувачів другого магістерського рівня вищої освіти, спеціальність 051 Економіка: досвід ХНПУ імені Г.С. Сковороди. Молодь i ринок. Щомісячний науково-педагогічний журнал. Дрогобич, 2021. № 4/190. С. 17 - 21.

3. Колногузенко Б.М. Методика роботи 3 хореографічним колективом. Ч.1. Хореографічна робота з дітьми. Харків, 2005. 153 с.

4. Осика М. С. Контроль та оцінювання навчальних досягнень учнів початкової школи. URL: https://vseosvita.ua/library/kontrol-taocinuvanna-navcalnih-dosagnen-molodsih-skolariv210647.html

5. Положенням про організацію практик в
Уманському державному педагогічному університеті імені Павла Тичини (денної та заочної форми навчання). URL : https://udpu.edu.ua/prouniversytet/dokumenty

6. Цетлин В. С. Функции практики в учебновоспитательном процессе и ее виды. Научныц журнал: Новые исследования в пед.науках. 1986. Выпуск 1. С.35-41.

\section{REFERENCES}

1. Abdullina, O. (1989). Pedagogicheskaya praktika studentov [Pedagogical practice of students]. Moscow, 175 p. [in Russian].

2. Vorozhbit-Gorbatyuk, V., Melnikova, O. \& Kabanska, G. (2021). Naukovo-pedagogichna praktyka zdobuvachiv drugogo magisterskogo rivnya vyshhoyi osvity, specialnist 051 Ekonomika: dosvid XNPU imeni G.S. Skovorody [Scientific and pedagogical practice of applicants for the second master's level of higher education, specialty 051 Economics: the experience of Gregory Skovoroda]. Youth \& market, no. 4 (190), pp. 17-21. [in Ukrainian].

3. Kolnoguzenko, B. (2005). Metodyka roboty z xoreografichnym kolektyvom [Methods of working with a choreographic team]. Part 1. Choreographic work with children. Kharkiv, 153 p. [in Ukrainian].

4. Osyka, M. Kontrol ta ocinyuvannya navchalnyx dosyagnen uchniv pochatkovoyi shkoly [Control and evaluation of educational achievements of primary school students]. Available at: https://vseosvita.ua/ library/kontrol-ta-ocinuvanna-navcalnih-dosagnenmolodsih-skolariv-210647.html [in Ukrainian].

5 . Regulations on the organization of internships at Uman State Pedagogical University named after Pavel Tychyna (full-time and part-time education) [Polozhennyam pro organizaciyu praktyk $\mathrm{v}$ Umanskomu derzhavnomu pedagogichnomu universyteti imeni Pavla Tychyny (dennoyi ta zaochnoyi formy navchannya)]. Available at: $\mathrm{https}$ ://udpu.edu.ua/ pro-universytet/dokumenty [in Ukrainian].

6. Zetlin, B. (1986). Funkcii praktiki v uchebnovospitatelnom processe i ee vidy [Functions of practice in the educational process and its types]. Scientific journal: New Research in Educational Sciences. Vol. 1, pp. 35-41. [in Russian].

Стаття надійшла до редакції 09.11.2021

\section{O58080ल2058080}

“Толовною метою освіти є створення хюдини, здатної робити нове, а не повторювати те, що вже зроблено прийдешніми поқоліннями”. 